\title{
Twentieth Century Precipitation Trends in the Upper Mzingwane Sub-catchment of the Northern Limpopo Basin, Zimbabwe
}

\author{
Auther Maviza ( $\sim$ auther.maviza@nust.ac.zw) \\ National University of Science and Technology https://orcid.org/0000-0002-5153-9212

\section{Stefan Grab} \\ University of Witwatersrand \\ Francois Engelbrecht \\ University of Witwatersrand
}

\section{Research Article}

Keywords: Precipitation trends, climate indices, extremes, Mzingwane, Zimbabwe

Posted Date: March 31st, 2021

DOI: https://doi.org/10.21203/rs.3.rs-350963/v1

License: (1) This work is licensed under a Creative Commons Attribution 4.0 International License.

Read Full License

Version of Record: A version of this preprint was published at Theoretical and Applied Climatology on April 15th, 2022. See the published version at https://doi.org/10.1007/s00704-022-04040-5. 


\section{Abstract}

This study evaluates precipitation trends in the upper Mzingwane sub-catchment (UMS) of Zimbabwe for the variables of annual precipitation, extremely wet days, consecutive wet days and consecutive dry days. The UMS is of strategic socio-economic significance in terms of its provision of water security and sustenance to livelihoods. The analysis is undertaken at four stations: Bulawayo Goetz, Filabusi, Mbalabala and Matopos National Park, and for the period 1921-2000. In general trends were found not to have local statistical significance, with the exception of the Matopos station (in the westernmost extent of UMS) which records significant increasing (declining) trends for most dryness (wetness) extreme indices. A general north to south-western declining precipitation gradient during the past $\sim 69$ years over the UMS was also found. The findings provide a baseline for future extended historical and future precipitation trend studies, and are important in the context of the socio-economic impacts of extreme events in this region.

\subsection{Introduction}

Pronounced hydroclimatic variability is an intrinsic to climate variability in Africa and often has negative implications for water security (Nash et al. 2016). Furthermore, there is evidence of drastic general warming and regional drying (i.e. decreasing annual precipitation) over large parts of the continent since the start of the twentieth century (Moss et al. 2010; Ramírez-Villegas and Thornton 2015; Miller and Croft 2018; Hannaford 2020). Over southern Africa (SA) for example, analysis of regionally averaged occurrence of climate extremes have revealed declining trends in total precipitation and increase in diurnal temperature range (DTR) coupled with rapid increases in maximum temperature extremes (New et al. 2006; Seneviratne et al. 2012). The decreases in total precipitation have over the past second half of the twentieth century been found to be associated with increasing (though insignificant) trends in extreme precipitation days and in maximum annual 5-day and 1-day precipitation (Frich et al. 2002).

To better understand future climatic trends and extremes in SA, various Global Climate Models (GCMs) and Regional Climate Models (RCMs) have been used by e.g. (Engelbrecht et al. 2013; Kalognomou et al. 2013; Shongwe et al. 2015; Dedekind et al. 2016; Archer et al. 2018; Maúre et al. 2018). Covering more of a decade of research, these projections have revealed a robust message of general drying being likely over SA under continued global warning. For instance, future projections of the southern African SA climate under $1.5^{\circ} \mathrm{C}$ and $2^{\circ} \mathrm{C}$ of global warming using CORDEX regional climate models by Maúre et al. (2018) reveal rainfall decreases of between 0.2 and $0.4 \mathrm{~mm} \mathrm{day}^{-1}$ over most of the central and western parts of the region. These decreases in precipitation are expected to be accompanied by worsening extremes characterised by increases (decreases) in the number of consecutive dry (wet) days over the region (New et al. 2006; Shongwe et al. 2015).

Many of the aforementioned studies and others (Klein-Tank and Können 2003; Kruger 2006; Kruger and Nxumalo 2017; Zarekarizi et al. 2018; Abbasnia and Toros 2019) have demonstrated the utility of various climate indices such as the World Meteorological Organization-Commission for Climatology (WMO - 
$\mathrm{CCL}$ ) and the Research Programme on Climate Variability and Predictability (CLIVAR) Expert Team for Climate Change Detection Monitoring and Indices (ETCCDI) climate indices (Peterson et al., 2001; Zhang et al., 2011) to explore trends in climate extremes over Africa and globally. However, climate trends remain relatively unexplored in Zimbabwe, especially at sub-national and provincial levels. This has been largely attributed to the paucity of reliable data (Gumindoga et al. 2017), absence of long multi-decadal scale datasets, large data gaps and the closure of meteorological recording stations (Peterson et al. 1998) due to lack of finances and technical expertise.

The available studies on historical climatic trends in Zimbabwe reveal that since 1950, the country has experienced variable changes in climate conditions. Daily minimum (maximum) temperatures rose by $2.6^{\circ} \mathrm{C}\left(2^{\circ} \mathrm{C}\right)$ over the last century, coupled with a mean annual precipitation decline of about $5 \%$ (Brown et al. 2012). The recorded rate of temperature increase is in the order of twice the rate the global average surface temperature has been increasing, consistent with the findings of Engelbrecht et al. (2015). Only a limited number of studies have explored trends in climate extremes in Zimbabwe. An exception is Aguilar et al. (2009) who founds no sifnificant increase in precipitation extremes over Zimbabwe between 19552006. Studies at the catchment level are also limited in number. Love et al. (2010) and Sibanda et al. (2018) noted a decline in total precipitation, declines in number of rainy days and increases in dry spells over the entire Mzingwane catchment. The most comprehensive study performed to date, based on 40 climate stations spread across Zimbabwe for the period 1892-2000 by Mazvimavi (2010), found no significant trends in extreme precipitation events. The study however was limited to studying extreme occurrences in seasonal and annual rainfall totals, and did not explore the potential impact of artificial change points in the data. Furthermore, this and other like studies used monthly data to ascertain trends, leaving the analysis of trends in climate statistics at a finer temporal resolution unaccounted for. Such analysis can be undertaken through indices based on daily data, which allow for an objective extraction of information concerning extremes which are known to adversely affect human and natural systems (Powell and Keim 2015; Abiodun et al. 2017; Schewe et al. 2019).

It is against this background that the current study uses historical daily precipitation data to compute WMO - CCL/CLIVAR ETCCDI climate change indices for south-western Zimbabwe. This is the first such study for Zimbabwe to assess historical (> 50 years) extreme precipitation events and trends using such core indices at a sub-catchment scale. Such an analysis is of particular value to decision and policy makers as it gives a comprehensive understanding of trends in precipitation extremes and their likely current and possibly future impacts on water resources infrastructure and livelihoods. This can further help inform current and future planning and identification of the types and range of climate resilience and adaptation options and opportunities to minimise climate extremes exposure risks.

\subsection{Materials And Methods}

We adapt the methodology of Kruger (2006), combined with the change detection test approach developed by Wang et al. (2010). We follow a 5-step approach entailing (1) data collection (digitizing of selected daily precipitation records), (2) pre-processing (cleaning and conversion as explained in 
Sect. 2.2), (3) testing for artificial change points in the datasets, (4) further quality checking for errors (i.e. check for duplicates, inconsistent/ unrealistic records), and (5) computation of the ETCCDI indices (Table 1) and testing for significance of trends. This study analyses trends of 10 ETCCDI extreme precipitation indices i.e. [Maximum 1-day precipitation amount (RX1day), Maximum 5-day precipitation amount (RX5day), Simple daily intensity index (SDII), Number of heavy precipitation days (R10), Number of very heavy precipitation days (R20), Consecutive dry days (CDD), Consecutive wet days (CWD), Very wet days (R95p), Extremely wet days (R99p) and Annual total wet-day precipitation (PRCPTOT) for the upper Mzingwane sub-catchment (UMS) in the northern Limpopo basin of Zimbabwe. The indices are measures to establish extreme precipitation events and trends over the period 1921-2000.

\subsection{Study area}

The Mzingwane catchment in the northern Limpopo basin, south-western Zimbabwe, is located in the southern Africa "dry slot" that stretches eastward from Namibia across southern Botswana, southern Zimbabwe and north-eastern South Africa (Engelbrecht et al. 2002). The UMS (Fig. 1) is one of the four subcatchments of the Mzingwane catchment. It covers $2138 \mathrm{~km}^{2}$ in areal extent and is located in Natural Region IV of Zimbabwe, which receives 450-650 mm of rainfall per annum (Görgens and Boroto 1997). This translates to a mean annual run-off of about $600 \mathrm{~mm}$, thus contributing most of the Mzingwane River's run-off. This river in return contributes almost $25 \%$ of the Limpopo River's flow volume, and is thus of considerable hydrological importance in the Limpopo basin. Mean annual $T_{\max }$ and $T_{\min }$ are $26^{\circ} \mathrm{C}$ and $15^{\circ} \mathrm{C}$ respectively while potential evaporation ranges between $1800 \mathrm{~mm}$ to $2000 \mathrm{~mm}$ per annum (Love et al. 2005). The region varies in elevation from $~ 864$ to 1560 metres. The ecosystem is typically semi-arid savannah with sparsely distributed woodlands species such as Brachystegia spiciformis, Colophospermum mopane, Terminalia, Acacia, Combretum, aloes, and grass species such as Hyparrhenia filipendula and Heteropogon contortus (Sawunyama et al. 2006).

The UMS extends across three districts: Insiza (to the east), Umzingwane (north-western extent) and Gwanda (to the south-western end) (Fig. 2), and hosts a population of over 50000 people. It has a diverse agro-ecological and socio-economic structured land-use system characterised by a mixture of commercial and subsistence agriculture such as small-scale low cost drip irrigation farming, dam recreational activities and private safari operations (Love et al. 2005). Gold panning is feasible in the Zimbabwean Craton greenstone belts and granitic terrain underlying most of the catchment (Ashton et al. 2002). The soils consist of moderately coarse grained kaolinitic sands (from the granites and Limpopo gneisses), very shallow to moderately shallow clays and loams, and very shallow sands derived from locally weathered basalts (Love et al. 2005; Sawunyama et al. 2006).

\subsection{Data collection and pre-processing}

Given limited access to daily precipitation data from the Meteorological Services Department of Zimbabwe (MSDZ), datasets utilised in this study were secured from the South African Weather Services (SAWS) library archives and digitised to soft copy format. Unfortunately, post 20th century data are only 
kept by the MSDZ, in both digital and hardcopy (undigitised format) and can only be obtained at prohibitive considerable expense. Criteria utilised in distilling the datasets were (1) spatial coverage (i.e., stations should be located in the UMS or at least within a $15 \mathrm{~km}$ radius from the UMS boundary), (2) have the longest time period possible and (3) retain a sufficient number of rainfall records/have minimum missing records. This process culminated in the selection of four stations: Bulawayo Goetz (BG), Matopos National Park (MNP), Mbalabala (Mb) and Filabusi (FI) (Table 2), representing the north, east, central and western extents of the study area respectively. Pre-processing was undertaken following the specifications by Zhang and Yang (2004), where data were converted and structured using the RClimDex software.

Considering that precipitation data series usually contain artificial shifts that could be related to changes in observation instruments, station location and the environmental setting etc. (Wang et al. 2010), it is important to test for artificial change points/discontinuities in the data (Wang 2003; Touré-Halimatou et al. 2017). Since we used the RClimDex software (which runs tests with an assumption that the data series have Gaussian errors) to compute indices, we first used the RHtests_dlyPrcp software package (Wang and Feng 2015) for detection and automatic adjustment of artificial shifts in daily precipitation data.

\subsubsection{Change point detection and data homogenisation}

We used the default software parameterisation (e.g. setting the nominal level of confidence at which to conduct the test $[p$. lev $=0.95])$; the maximum number of years of data immediately before or after a change point to be used for estimating the Probability Distribution Function (PDF) (set to use the whole data set without segmentation); and the lower threshold of precipitation $(p t h r=0.0)$. The homogenisation procedure was divided into two primary steps: (i) detection of inhomogeneities (change points) and (ii) calculation and application of data adjustment parameters for each station. The process follows an iterative run of the 'StepSize' function to help detect statistically insignificant change points and homogenise the dataset by applying the Box-Cox transformation technique. The Box-Cox transformation also lowers False Alarm Rates (FARs) and improves extreme trend detection power (Osborne 2010). Details of this procedure are described in detail by Wang and Feng (2013). Table 3 summaries results for this stage of the analysis, which presents the number of significant change points. Given that no change points were identified for BG, data were used as is.

\subsection{Data analysis}

\subsubsection{Computation of Indices}

The RClimDex software used in this study only computes monthly indices if no more than three days of data are missing in a given month, while annual values are calculated if no more than 15 days are missing in a given year. Annual values are only calculated if data are available for all 12 months, while threshold indices are computed if at least $75 \%$ of data are present. The computed indices can be grouped into five broad categories: Absolute indices (RX1Day and RX5DAY); percentile-based indices (R95P and 
R99P); threshold indices (R10MM and R20MM); duration indices (CDD and CWD); and others (PRCPTOT and SDII). Algorithms for computation of the indices are presented in Table 1 and details for internal processes of the RClimDex software refer to Zhang and Yang (2004).

\subsubsection{Trends and statistical analysis}

In order to detect trends, statistical significance and the slopes of the index series, we employed the nonparametric Mann-Kendall (MK) trend test (Mann 1945; Kendall 1975) and the Sen's Slope Estimator (Sen 1968) respectively. These have been widely used to evaluate significance of trends in numerous studies e.g. (Haylock et al. 2006; Sousa et al. 2011; Rahayu 2013; Dube and Nhamo 2018; Gebrechorkos et al. 2019; Wang et al. 2020).

\subsection{Results}

\subsection{Trends in annual total precipitation (PRCPTOT)}

Figure 2 shows that all stations had declining trends in annual total precipitation over the past 69 years with the exception of Bulawayo Goetz which had a marginal insignificant increasing trend $\left(Q_{\text {med }}=-0.626\right.$, $\mathrm{p}=0.568$ ). Matopos station however was the only station recording a significant declining trend in annual total precipitation $\left(Q_{m e d}=-3.073, \mathrm{p}=0.011\right)$, indicating potentially stronger drying in the western part of the UMS. These results disaggregate and present in greater detail the general declining annual total precipitation trends reported by Love et al. (2001) in 10 climate stations in the Mzingwane catchment since 1980. Though other stations show statistically insignificant declining trends, the spatially coherent pattern of decline indicate potential adverse impacts on livelihoods especially rain-fed agricultural activities in the UMS.

\subsection{Absolute indices (RX1DAY and RX5DAY)}

Trend analysis for RX1DAY and RX5DAY are presented in Fig. 3 and Fig. 4 respectively, while the trend significance results are shown in Table 4. RX1Day trends for all but Matopos National Park station were positive and statistically insignificant. Overall, marginally increasing trends in all the UMS zones (mean = $0.2 \mathrm{~mm} / \mathrm{annum}$ ) were found, expect for the western extent which showed a declining trend (mean = $-0.463 \mathrm{~mm} /$ annum) over the study period. Bulawayo Goetz and Filabusi (Mbalabala) stations had insignificant negative (positive) trends for RX5DAY. At Matopos National Park station a significant negative trend $\left(Q_{\text {med }}=-0.672, \mathrm{p}=0.018\right)$ was recorded. Three of the stations exhibit declining RX5Day trends, (mean $=-0.879 \mathrm{~mm} /$ annum). The negative (significant) trends in the western extent of UMS suggest a decline in extreme events in the form of 5-day maximum precipitation.

\subsection{Percentile-based indices (R95p and R99p)}

No significant trends were detected for historical very wet day (R95p) and extremely wet day (R99p) events over the study time period for three of the four stations. The exception is MNP, which registered a significant declining trend $\left(Q_{\text {med }}=-1.41 ; \mathrm{p}=0.029\right)$ for R95p and an insignificant declining trend for R99p 
(see Table 4). These declining trends over MNP are consistent with the earlier discussed significant declining trend in total annual precipitation $\left(Q_{\text {med }}=-3.073, \mathrm{p}=0.011\right.$ over the western extent of the UMS marked by a drastic drop in R99p from $150 \mathrm{~mm}$ to about $50 \mathrm{~mm}$ between the 1970 s and $1990 \mathrm{~s}$. Trends for R95p and R99p are shown in Fig. 5 and Fig. 6.

\subsection{Threshold and other indices (R10, R20 and SDII)}

Results for heavy rainfall days above $10 \mathrm{~mm}$ (R10) and $20 \mathrm{~mm}$ (R20) per day (Fig. 7 and Fig. 8) reveal that three of the stations record declining but statistically insignificant trends (mean R10/R20 $=19 / 9$ days respectively), while MNP records significant negative trends both indices i.e. R10 (R20) $Q_{\text {med }}=-0.093, \mathrm{p}=$ $0.023\left(Q_{\text {med }}=-0.075, \mathrm{p}=0.003\right)$. The magnitude of these trends is notably very low (below $1 \%$ ) at all stations (Table 4). These declining trends in R20 and R10 were matched with declining trends of PRCPTOT (as earlier indicated in Fig. 2) at three of the stations, the exception being at BG which recorded an increasing, albeit insignificant trend $\left(Q_{m e d}=0.626, p=0.568\right)$. Over the same period, trends in the intensity of daily precipitation (depicted by the SDII) significantly increased (decreased) for FI (MNP), $Q_{\text {med }}=-0.033, \mathrm{p}=0.033\left(Q_{\text {med }}=-0.035, \mathrm{p}=0.004\right)$, while the remaining two stations recorded marginally positive but insignificant trends.

\subsection{Duration indices (CDD and CWD)}

The indices CDD (CWD) are a measure of dry (wet) 'spell duration' in days. Results reveal $\mathrm{Q}_{\text {med }}$ (p-values) ranging between -0.075 and -0.543 (0.099 and 0.857) for CDD, indicating insignificant decreasing trends (Fig. 9) of consecutive dry days at three of the stations, with the exception of Fl which had an insignificant increasing trend $\left(Q_{\text {med }}=0.286, p=0.353\right)$. Similar insignificant, declining trends are recorded for CWD with the exception of $\mathrm{Fl}$ which had an insignificant increasing trend $\left(Q_{\text {med }}=0.0001, p=0.952\right)$ (Fig. 10). Decreasing trends in CDD do not necessarily translate into an improvement in precipitation conditions considering the recorded negative trends in CWD over the most of stations in the UMS.

\subsection{Discussion}

Results from this study region depict a scenario of long-term drying over the 69 year period, most particularly so over the westernmost portion (represented by the MNP station). Such a drying trend is consistent with previous findings for other parts of southern Africa e.g. (Daron 2014; Morioka et al. 2015; Scholes et al. 2015) and Zimbabwe in general (Brazier 2015; Makuvaro et al. 2017; Nangombe et al. 2018). However, while there is generally decreasing total annual precipitation (mean $=-0.54 \mathrm{~mm} /$ annum), this is accompanied by increased precipitation intensity (marked by increasing maximum 1-day precipitation amounts (RX1Day)) over most of the study region. While Love et al. (2006) found a general declining trend in annual total precipitation over the entire Mzingwane catchment from years 1931 to 2003, our findings provide a finer-scale detail on how this declining PRCPTOT trend manifests at a subregional (or sub-catchment) scale for the UMS over the period 1921-2000, including an analysis of extreme events. 
In addition, given the fact that trends in precipitation intensity over longer periods (revealed by RX5DAY trends) demonstrate a general declining trend, the northern and interior extents of the UMS indicate general increasing trends in the very wet precipitation index (R95p), while the westernmost extent records a significant declining trend. Coupled with this, the UMS has generally experienced marginally positive (statistically insignificant) trends overall in both R95p and R99p though a declining trend in the westernmost extent is noted for the same indices. There is hence an increasing drying trend over time from north to south-west extent in the UMS which is slightly different from the general north to south gradient reported by authors such as Masvopo (2012), Love et al. (2005) and Sibanda et al. (2018).

Declining trends in threshold indices (R10 and R20) indicate that there are fewer days with daily precipitation above $10 \mathrm{~mm}$ (-19/days/decade) and $20 \mathrm{~mm}$ (-9days/decade) respectively. This may imply that increased precipitation intensities (RX1Day) are concentrated on extreme precipitation days (e.g. R95p) as also suggested in similar studies such as Berhane et al. (2020) in Ethiopia and Kruger (2006) in South Africa. The time-averaged measures of precipitation which have often been used in past climate trend analysis studies in this region e.g. (Unganai and Mason 2002; Klein-Tank and Können 2003; Dike et al. 2019) do not capture the that increases in precipitation intensity partially compensate for decreases in frequency.

Results for CWD (wet spells) show a general negative trend in most part of the UMS, apart from Filabusi which has a marginal increasing (statistically insignificant) trend. The westernmost region (MNP) registered a decreasing trend ( $\sim 2$ days/decade), hence complementing and elaborating further on the characteristics of the drying trend depicted by indices such as the PRCPTOT for the same western subregion. Further to this, declining trends in the consecutive number of dry days (dry spells) (CDD) were noted in all but the eastern sub-region (Table 4). The decline in dry spells does not necessarily imply commensurate favourable/ normal precipitation conditions as might be assumed. This could be attributed to the fact that CDD (and CWD) are very sensitive indices, such that even single day rainfall events are enough to terminate a CDD or CWD period as indicated by Hofstra and New (2009). This, however, does not diminish the utility of the CDD index as it has been widely used as a meaningful measure of unusually dry conditions and a potential proxy drought indicator (Griffiths 2007).

An understanding of these temporal changes in climatic extremes and their trends is important given the impacts that extreme events have on society and the natural environment (Abiodun et al. 2017; Bell et al. 2018; Perera et al. 2020). For instance, trends for the RX1DAY and very wet days (R95p) are relevant for planning and projecting changes in demands on drainage and sewerage systems at different locations (Klein-Tank and Können 2003), while the CDD can serve as a proxy for drought detection and (Skierlo et al. 2017; Sharma et al. 2020) thus allows for appropriate water resource planning and management. In this study, new information on climate extremes and trends could be useful in the design of new and/ upgrading of old water supply storage infrastructure such the Insiza, Mzingwane and Inyankuni dams located within the UMS so as to achieve targeted water security goals for the city of Bulawayo and the surrounding communities by the local and central government of Zimbabwe. Similarly, the Zimbabwe National Water Authority (ZINWA) could, for instance, leverage the R95p, R99p and CWD trends to guide 
decision making pertaining proper sizing and/ upgrading of flood control systems to cope with more short and intense precipitation events which have been associated with destructive, intermittent flash floods (Chingombe et al. 2015; Eccles et al. 2019). The findings can also be used for climate monitoring, targeting approaching extreme events which can inform proactive impact mitigation plans as highlighted by Davis and Hirji (2014).

\subsection{Conclusion}

Notwithstanding the limitations of access of up-to-date station precipitation data for our study area, we were able to successfully analyse and demonstrate the utility of climate extreme indices in understanding historical precipitation extremes in the UMS for the period 1921-2000. Most computed index values in this study showed negative, statistically insignificant but spatially coherent precipitation extreme trends across the UMS. The exception is for the westernmost extent of the area, which showed significant negative precipitation extreme trends indicative of drying over time. A general shift towards shorter very wet periods with more intense precipitation is noted in the study area. Overall, a general north to southwestern declining precipitation gradient across the UMS is identified contrary to the general north to south gradient identified in previous studies. Findings from this study could also serve as a baseline in followup studies aimed at extended historical analysis, modelling future trends in extreme precipitation conditions and the likely impacts in the UMS using alternative datasets such as CCAM and CHIRPS.

\section{Declarations}

\section{Funding:}

Partial financial support (tuition) was received by Auther Maviza from The National University of Science and Technology to undertake this study at the University of the Witwatersrand.

\section{Conflicts of interest/Competing interests:}

All authors declare that they do not have any conflicts of interest to disclose that are relevant to the contents of this article.

\section{Availability of data and material:}

Not applicable

\section{Code availability:}

Not applicable 


\section{Author contributions:}

Conceptualisation: Auther Maviza; Methodology: Auther Maviza, Francois Engelbrecht; Data curation: Auther Maviza, Stefan Grab; Software: Auther Maviza; Data analysis: Auther Maviza; Visualisation: Auther Maviza, Francois Engelbrecht; Writing - Original draft preparation: Auther Maviza; Writing - Reviewing and editing: Auther Maviza, Stefan Grab, Francois Engelbrecht

\section{Compliance with Ethical Standards}

Ethics approval: Not applicable

\section{Consent to participate:}

Not applicable

\section{Consent for publication:}

All authors agreed with the content and gave explicit consent to submit this work for publication.

\section{References}

1. Abbasnia M, Toros $H$ (2019) Analysis of long-term changes in extreme climatic indices: a case study of the Mediterranean climate, Marmara Region, Turkey. In: Meteorology and Climatology of the Mediterranean and Black Seas. Springer, Switzerland, pp 141-153. doi:https://doi.org/10.1007/978-3030-11958-4_9

2. Abiodun BJ, Adegoke J, Abatan AA, Ibe CA, Egbebiyi TS, Engelbrecht F, Pinto I (2017) Potential impacts of climate change on extreme precipitation over four African coastal cities Climatic Change 143:399-413 doi:10.1007/s10584-017-2001-5

3. Aguilar E et al. (2009) Changes in temperature and precipitation extremes in western central Africa, Guinea Conakry, and Zimbabwe, 1955-2006 Journal of Geophysical Research: Atmospheres 114 doi:10.1029/2008jd011010

4. Archer ERM, Engelbrecht FA, Hänsler A, Landman W, Tadross M, Helmschrot J (2018) Seasonal prediction and regional climate projections for southern Africa. In. Klaus Hess Publishers, Göttingen \& Windhoek, pp 14-21. doi:doi:10.7809/b-e.00296

5. Ashton P, Love D, Mahachi H, Dirks P An Overview of the Impact of Mining and Mineral Processing Operations on Water Resources and Water Quality in the Zambezi, Limpopo and Olifants Catchments in Southern Africa. In, 2002. 
6. Bell JE et al. (2018) Changes in extreme events and the potential impacts on human health Journal of the Air \& Waste Management Association 68:265-287 doi:10.1080/10962247.2017.1401017

7. Berhane A, Hadgu G, Worku W, Abrha B (2020) Trends in extreme temperature and rainfall indices in the semi-arid areas of Western Tigray, Ethiopia Environmental Systems Research 9:3 doi:10.1186/s40068-020-00165-6

8. Brazier A (2015) Climate Change in Zimbabwe: Facts for Planners and Decision Makers. Konradadenauer-stiftung, Harare, Zimbabwe

9. Brown D et al. (2012) Climate change impacts, vulnerability and adaptation in Zimbabwe. International Institute for Environment and Development, London (UK)

10. Chingombe W, Pedzisai E, Manatsa D, Mukwada G, Taru P (2015) A participatory approach in GIS data collection for flood risk management, Muzarabani district, Zimbabwe Arabian Journal of Geosciences 8:1029-1040 doi:10.1007/s12517-014-1265-6

11. Daron JD (2014) Regional climate message: Southern Africa. CARIAA and ASSAR, Rondebosch, Cape Town (South Africa)

12. Davis R, Hirji R (2014) Climate Change and Water Resources Planning, Development and Management in Zimbabwe, 1 edn. World Bank, Harare, Zimbabwe

13. Dedekind Z, Engelbrecht FA, Van der Merwe J (2016) Model simulations of rainfall over southern Africa and its eastern escarpment Water SA 42:129-143

14. Dike VN, Lin Z, Wang Y, Nnamchi H (2019) Observed trends in diurnal temperature range over Nigeria Atmospheric and Oceanic Science Letters 12:131-139 doi:10.1080/16742834.2019.1570688

15. Dube K, Nhamo G (2018) Climate variability, change and potential impacts on tourism: Evidence from the Zambian side of the Victoria Falls Environmental Science \& Policy 84:113-123 doi:https://doi.org/10.1016/j.envsci.2018.03.009

16. Eccles $\mathrm{R}$, Zhang $\mathrm{H}$, Hamilton $\mathrm{D}$ (2019) A review of the effects of climate change on riverine flooding in subtropical and tropical regions Journal of Water and Climate Change 10:687-707 doi:10.2166/wcc.2019.175

17. Engelbrecht CJ, Engelbrecht FA, Dyson LL (2013) High-resolution model-projected changes in midtropospheric closed-lows and extreme rainfall events over southern Africa International Journal of Climatology 33:173-187 doi:10.1002/joc.3420

18. Engelbrecht $F$ et al. (2015) Projections of rapidly rising surface temperatures over Africa under low mitigation Environmental Research Letters 10:085004 doi:10.1088/1748-9326/10/8/085004

19. Engelbrecht FA, Rautenbach CJDW, McGregor JL, Katzfey JJ (2002) January and July climate simulations over the SADC region using the limited-area model DARLAM Water SA 28:361-374 doi:http://10.10520/ejc116049

20. Frich P, Alexander LV, Della-Marta P, Gleason B, Haylock M, Klein-Tank AMG, Peterson T (2002) Observed coherent changes in climatic extremes during the second half of the twentieth century Climate Research 19:193-212 
21. Gebrechorkos SH, Hülsmann S, Bernhofer C (2019) Changes in temperature and precipitation extremes in Ethiopia, Kenya, and Tanzania International Journal of Climatology 39:18-30 doi:10.1002/joc.5777

22. Görgens AHM, Boroto RA River: flow balance anomalies, surprises and implications for integrated water resources management. In: 8th South African National Hydrology Symposium, Pretoria, South Africa, 1997.

23. Griffiths GM (2007) Changes in New Zealand daily rainfall extremes 1930 - 2004 Weather and Climate 27:3-44

24. Gumindoga W, Rientjes THM, Haile A, Makurira H, Reggiani P (2017) Performance of bias correction schemes for CMORPH rainfall estimates in the Zambezi River Basin Hydrology and Earth Systems Science:1-27 doi:10.5194/hess-2017-385

25. Hannaford M (2020) Climate Change and Society in Southern African History. Oxford University Press, Oxford (UK). doi:http://10.1093/acrefore/9780190277734.013.294

26. Haylock MR et al. (2006) Trends in Total and Extreme South American Rainfall in 1960-2000 and Links with Sea Surface Temperature Journal of Climate 19:1490-1512 doi:10.1175/jcli3695.1

27. Hofstra N, New M (2009) Spatial variability in correlation decay distance and influence on angulardistance weighting interpolation of daily precipitation over Europe International Journal of Climatology 29:1872-1880 doi:10.1002/joc.1819

28. Kalognomou E-A et al. (2013) A Diagnostic Evaluation of Precipitation in CORDEX Models over Southern Africa Journal of Climate 26:9477-9506

29. Kendall M (1975) Multivariate analysis. Charles Griffin,

30. Klein-Tank AMG, Können GP (2003) Trends in Indices of Daily Temperature and Precipitation Extremes in Europe, 1946-99 Journal of Climate 16:3665-3680 doi:10.1175/15200442(2003)016<3665:tiiodt $>2.0 . c 0 ; 2$

31. Kruger AC (2006) Observed trends in daily precipitation indices in South Africa: 1910-2004 International Journal of Climatology 26:2275-2285 doi:10.1002/joc.1368

32. Kruger AC, Nxumalo MP (2017) Historical rainfall trends in South Africa: 1921-2015 Water SA 43:285-297

33. Love D, Taigbenu AE, Jonker L (2005) An overview of the Mzingwane Catchment, Zimbabwe (PN17).

34. Love D, Uhlenbrook S, Corzo-Perez G, Twomlow S, van der Zaag P (2001) Rainfall interception, evaporation and runoff relationships in a semi-arid catchment, northern Limpopo basin, Zimbabwe Hydrological Sciences Journal 55:687-703 doi:10.1080/02626667.2010.494010

35. Love D, Uhlenbrook S, Madamombe E, Twomlow S, Zaag P (2006) An evaluation of climate and runoff variability and associated livelihood risks in the Mzingwane Catchment Limpopo Basin Zimbabwe

36. Love D, Uhlenbrook S, Twomlow S, van der Zaag P (2010) Changing hydroclimatic and discharge patterns in the northern Limpopo Basin, Zimbabwe Water SA 36:335-350 
37. Makuvaro V, Murewi CTF, Dimes J, Chagonda I (2017) Are Smallholder Farmers' Perceptions of Climate Variability and Change Supported by Climate Records? A Case Study of Lower Gweru in Semiarid Central Zimbabwe Weather, Climate, and Society 10:35-49 doi:10.1175/wcas-d-16-0029.1

38. Mann HB (1945) Nonparametric Tests Against Trend Econometrica 13:245-259 doi:10.2307/1907187

39. Masvopo TH (2012) Evaluation of the groundwater potential of the Malala alluvial aquifer, lower Mzingwane River, Zimbabwe

40. Maúre $\mathrm{G}$ et al. (2018) The southern African climate under $1.5^{\circ} \mathrm{C}$ and $2{ }^{\circ} \mathrm{C}$ of global warming as simulated by CORDEX regional climate models Environmental Research Letters 13:065002

41. Mazvimavi $D$ (2010) Investigating changes over time of annual rainfall in Zimbabwe Hydrology and Earth System Sciences 14:2671-2679 doi:http://10.5194/hess-14-2671-2010

42. Miller B, Croft J (2018) Planet has only until 2030 to stem catastrophic climate change, experts warn World 8

43. Morioka Y, Engelbrecht F, Behera SK (2015) Potential Sources of Decadal Climate Variability over Southern Africa Journal of Climate 28:8695-8709 doi:10.1175/jcli-d-15-0201.1

44. Moss $\mathrm{RH}$ et al. (2010) The next generation of scenarios for climate change research and assessment Nature 463:747-756 doi:10.1038/nature08823

45. Nangombe S, Madyiwa S, Wang J (2018) Precursor conditions related to Zimbabwe's summer droughts Theoretical \& Applied Climatology 131:413

46. Nash DJ et al. (2016) African hydroclimatic variability during the last 2000 years Quaternary Science Reviews 154:1-22 doi:https://doi.org/10.1016/j.quascirev.2016.10.012

47. New M et al. (2006) Evidence of trends in daily climate extremes over southern and west Africa Journal of Geophysical Research: Atmospheres 111 doi:10.1029/2005jd006289

48. Osborne J (2010) Improving your data transformations: Applying the Box-Cox transformation Practical Assessment, Research, and Evaluation 15:12

49. Perera ATD, Nik VM, Chen D, Scartezzini J-L, Hong T (2020) Quantifying the impacts of climate change and extreme climate events on energy systems Nature Energy 5:150-159 doi:10.1038/s41560-020-0558-0

50. Peterson TC et al. (1998) Homogeneity adjustments of in situ atmospheric climate data: a review International Journal of Climatology 18:1493-1517 doi:10.1002/(sici)10970088(19981115)18:13<1493::aid-joc329>3.0.co;2-t

51. Powell EJ, Keim BD (2015) Trends in Daily Temperature and Precipitation Extremes for the Southeastern United States: 1948-2012 Journal of Climate 28:1592-1612 doi:10.1175/jcli-d-1400410.1

52. Rahayu A (2013) Identification of Climate Change with Generalized Extreme Value (GEV) Distribution Approach Journal of Physics: Conference Series 423:012026 doi:10.1088/1742-6596/423/1/012026

53. Ramírez-Villegas J, Thornton PK (2015) Climate change impacts on African crop production 
54. Sawunyama T, Senzanje A, Mhizha A (2006) Estimation of small reservoir storage capacities in Limpopo River Basin using geographical information systems (GIS) and remotely sensed surface areas: Case of Mzingwane catchment Physics and Chemistry of the Earth, Parts A/B/C 31:935-943 doi:http://dx.doi.org/10.1016/j.pce.2006.08.008

55. Schewe J et al. (2019) State-of-the-art global models underestimate impacts from climate extremes Nature Communications 10:1005 doi:10.1038/s41467-019-08745-6

56. Scholes RJ, Scholes M, Lucas M (2015) Climate Change : Briefings From Southern Africa. Wits University Press, Johannesburg

57. Sen PK (1968) Estimates of the Regression Coefficient Based on Kendall's Tau Journal of the American Statistical Association 63:1379-1389 doi:10.1080/01621459.1968.10480934

58. Seneviratne SI et al. (2012) Changes in climate extremes and their impacts on the natural physical environment: An overview of the IPCC SREX report. In: Field CB (ed) Managing the risks of extreme events and disasters to advance climate change adaptation : Special Report of the Intergovernmental Panel on Climate Change, vol 14. Cambridge University Press, p 12566

59. Sharma S, Khadka N, Hamal K, Shrestha D, Talchabhadel R, Chen Y (2020) How Accurately Can Satellite Products (TMPA and IMERG) Detect Precipitation Patterns, Extremities, and Drought Across the Nepalese Himalaya? Earth and Space Science 7:e2020EA001315 doi:https://doi.org/10.1029/2020EA001315

60. Shongwe ME, Lennard C, Liebmann B, Kalognomou E-A, Ntsangwane L, Pinto I (2015) An evaluation of CORDEX regional climate models in simulating precipitation over Southern Africa Atmospheric Science Letters (John Wiley \&amp; Sons, Inc ) 16:199-207

61. Sibanda S, Grab SW, Ahmed F (2018) Spatio-temporal temperature trends and extreme hydroclimatic events in southern Zimbabwe South African Geographical Journal 100:210-232 doi:10.1080/03736245.2017.1397541

62. Skierlo F, Miegel K, Gómez-Hernández JJ (2017) NEW PRECIPITATION INDICES FOR MONITORING DROUGHT-AN ANALYSIS OF THE PRECIPITATION REGIMES OF GERMANY AND THE IBERIAN PENINSULA IN THE COURSE OF CLIMATE CHANGE International Multidisciplinary Scientific GeoConference: SGEM 17:453-460

63. Sousa PM, Trigo RM, Aizpurua P, Nieto R, Gimeno L, Garcia Herrera R (2011) Trends and extremes of drought indices throughout the 20th century in the Mediterranean Natural hazards and earth system sciences 11:33-51

64. Touré-Halimatou A, Kalifa T, Kyei-Baffour N (2017) Assessment of changing trends of daily precipitation and temperature extremes in Bamako and Ségou in Mali from 1961- 2014 Weather and Climate Extremes 18:8-16 doi:https://doi.org/10.1016/j.wace.2017.09.002

65. Unganai LS, Mason SJ (2002) Long-range predictability of Zimbabwe summer rainfall International Journal of Climatology 22:1091-1103 doi:http://10.1002/joc.786

66. Wang XL (2003) Comments on "Detection of Undocumented Changepoints: A Revision of the TwoPhase Regression Model" Journal of Climate 16:3383-3385 doi:10.1175/1520- 
0442(2003)016<3383:codouc $>2.0 . c 0 ; 2$

67. Wang XL, Chen H, Wu Y, Feng Y, Pu Q (2010) New Techniques for the Detection and Adjustment of Shifts in Daily Precipitation Data Series Journal of Applied Meteorology and Climatology 49:24162436 doi:10.1175/2010jamc2376.1

68. Wang XL, Feng Y (2013) RHtests_dlyPrcp user manual Clim Res Div Atmospheric Sci Technol Dir Sci Technol Branch Environ Can Tor Ont Can Retrieved Febr 25:2014 doi:DOI:10.1175/2007/JTECHA982.1.

69. Wang XL, Feng Y (2015) Overview of the RHtests_dlyPrcp software package for homogenization of daily precipitation doi:DOI:10.1175/2007/JTECHA982.1.

70. Wang Y, Xu Y, Tabari H, Wang J, Wang Q, Song S, Hu Z (2020) Innovative trend analysis of annual and seasonal rainfall in the Yangtze River Delta, eastern China Atmospheric Research 231:104673 doi:https://doi.org/10.1016/j.atmosres.2019.104673

71. Zarekarizi M, Rana A, Moradkhani H (2018) Precipitation extremes and their relation to climatic indices in the Pacific Northwest USA Climate Dynamics 50:4519-4537 doi:10.1007/s00382-017$3888-2$

72. Zhang X, Yang F (2004) RClimDex (1.0) user manual Climate Research Branch Environment Canada 22

\section{Tables}

Due to technical limitations, tables are only available as a download in the Supplemental Files section.

\section{Figures}




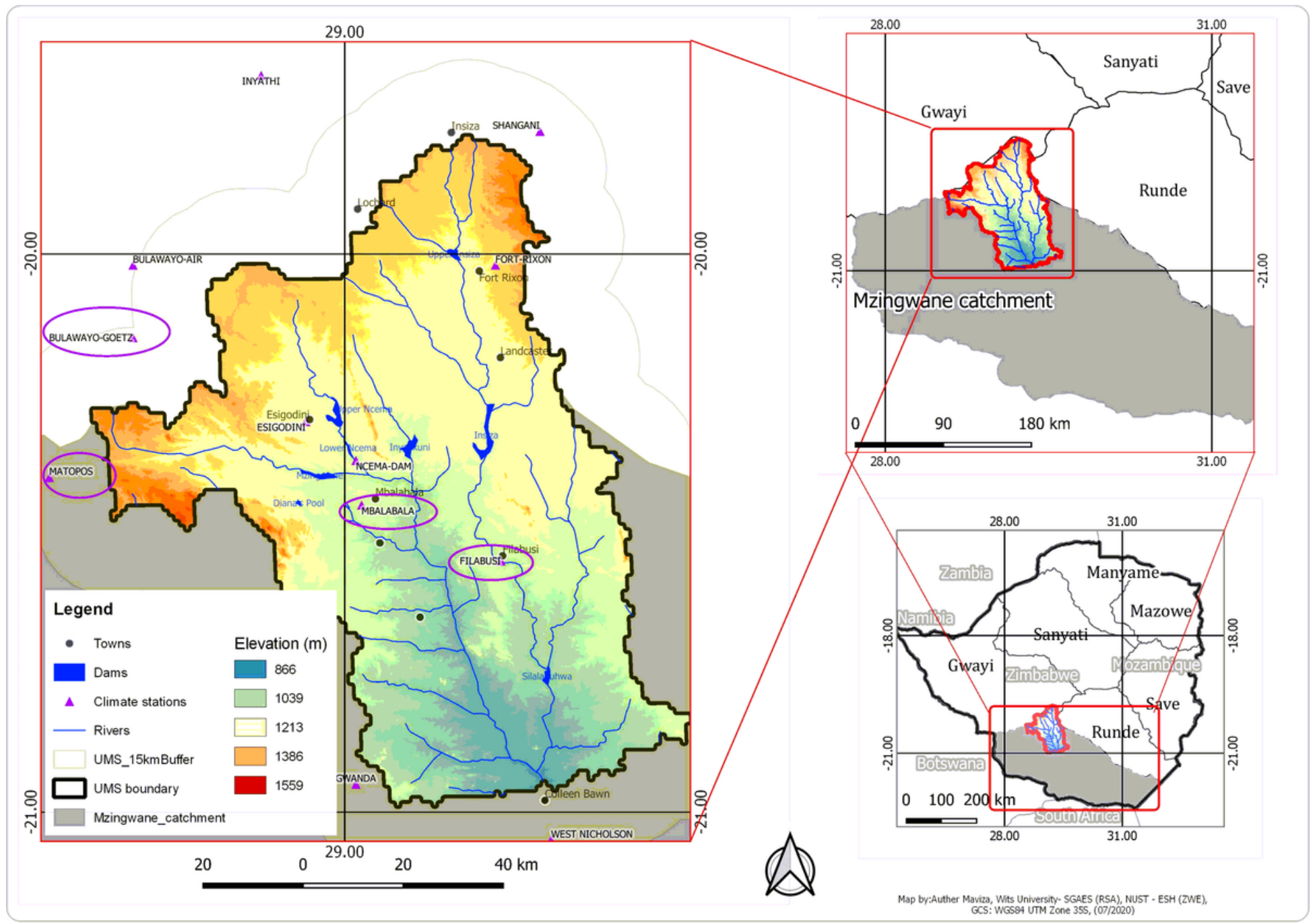

\section{Figure 1}

Location of the four selected climate stations used in this study (marked with purple ellipses) inside and within $15 \mathrm{~km}$ distance of the UMS Note: The designations employed and the presentation of the material on this map do not imply the expression of any opinion whatsoever on the part of Research Square concerning the legal status of any country, territory, city or area or of its authorities, or concerning the delimitation of its frontiers or boundaries. This map has been provided by the authors. 

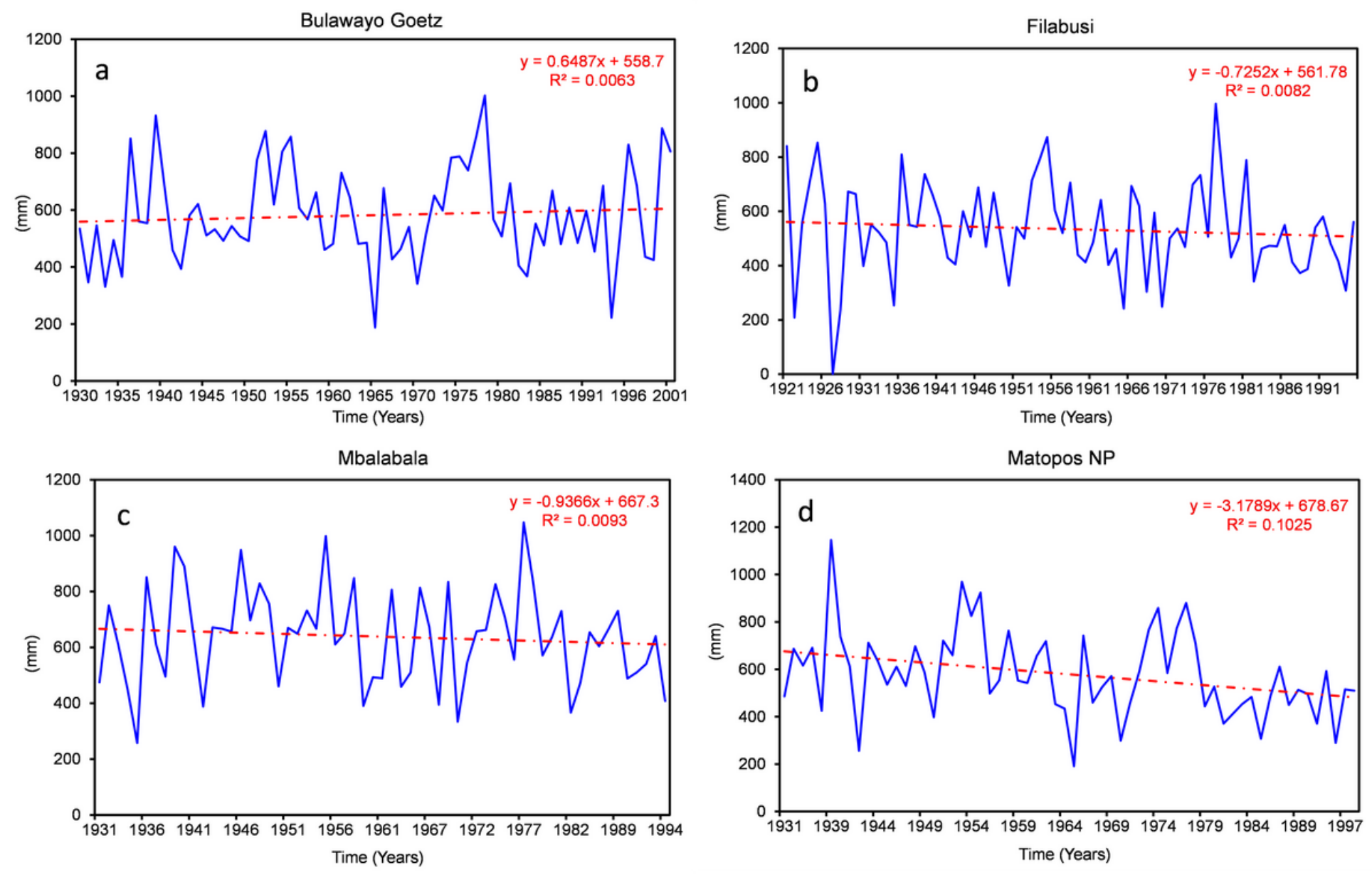

\section{Figure 2}

PRCPTOT series and trends for the four stations (a - Bulawayo Goetz, b - Filabusi, c - Mbalabala and d Matopos NP). Red dotted lines $=$ linear trends 

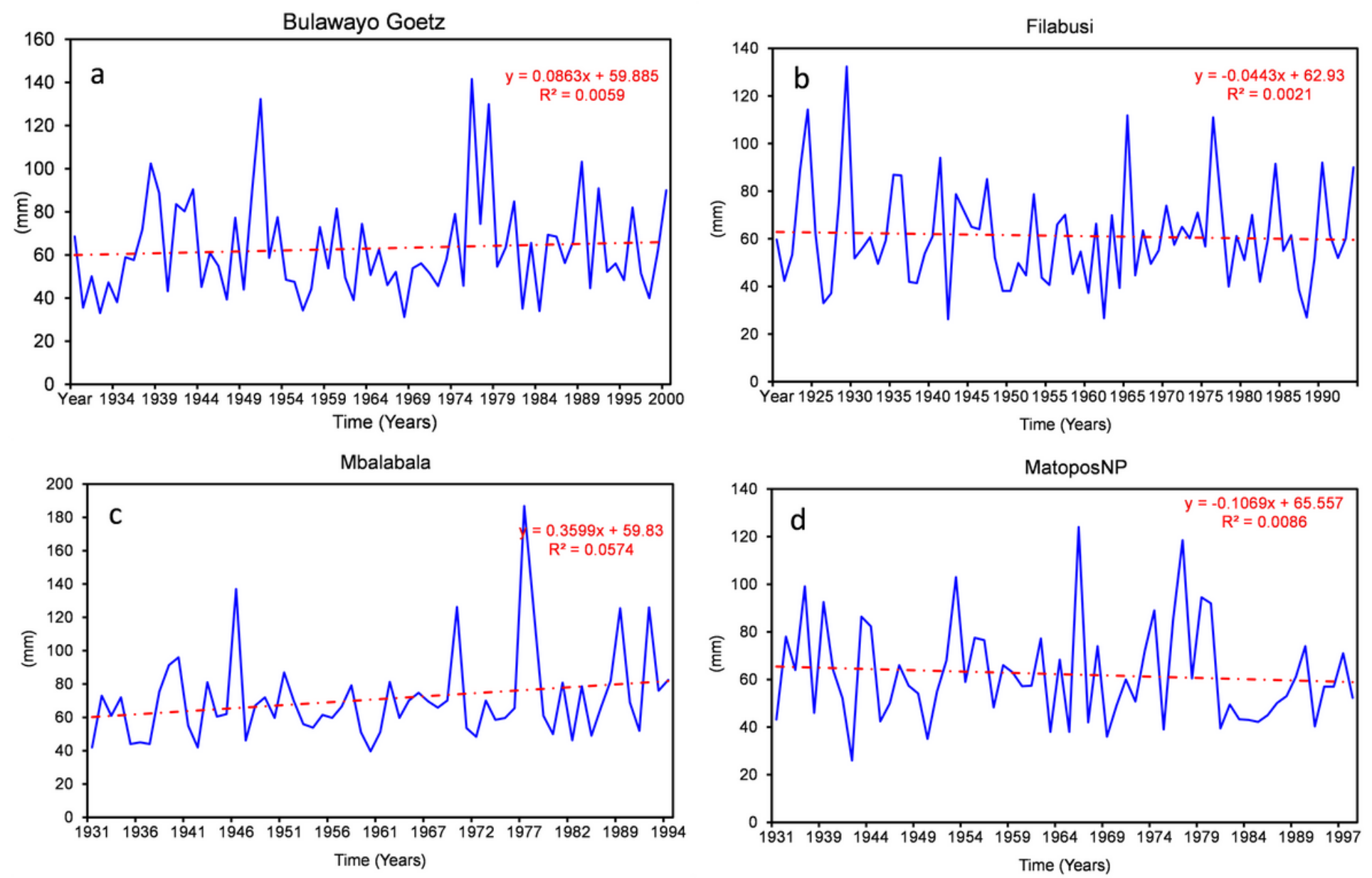

Figure 3

RX1DAY series trends for the four stations (a - Bulawayo Goetz, b - Filabusi, c - Mbalabala and d Matopos NP). The red dotted lines are linear trend lines illustrating weak and insignificant trends 

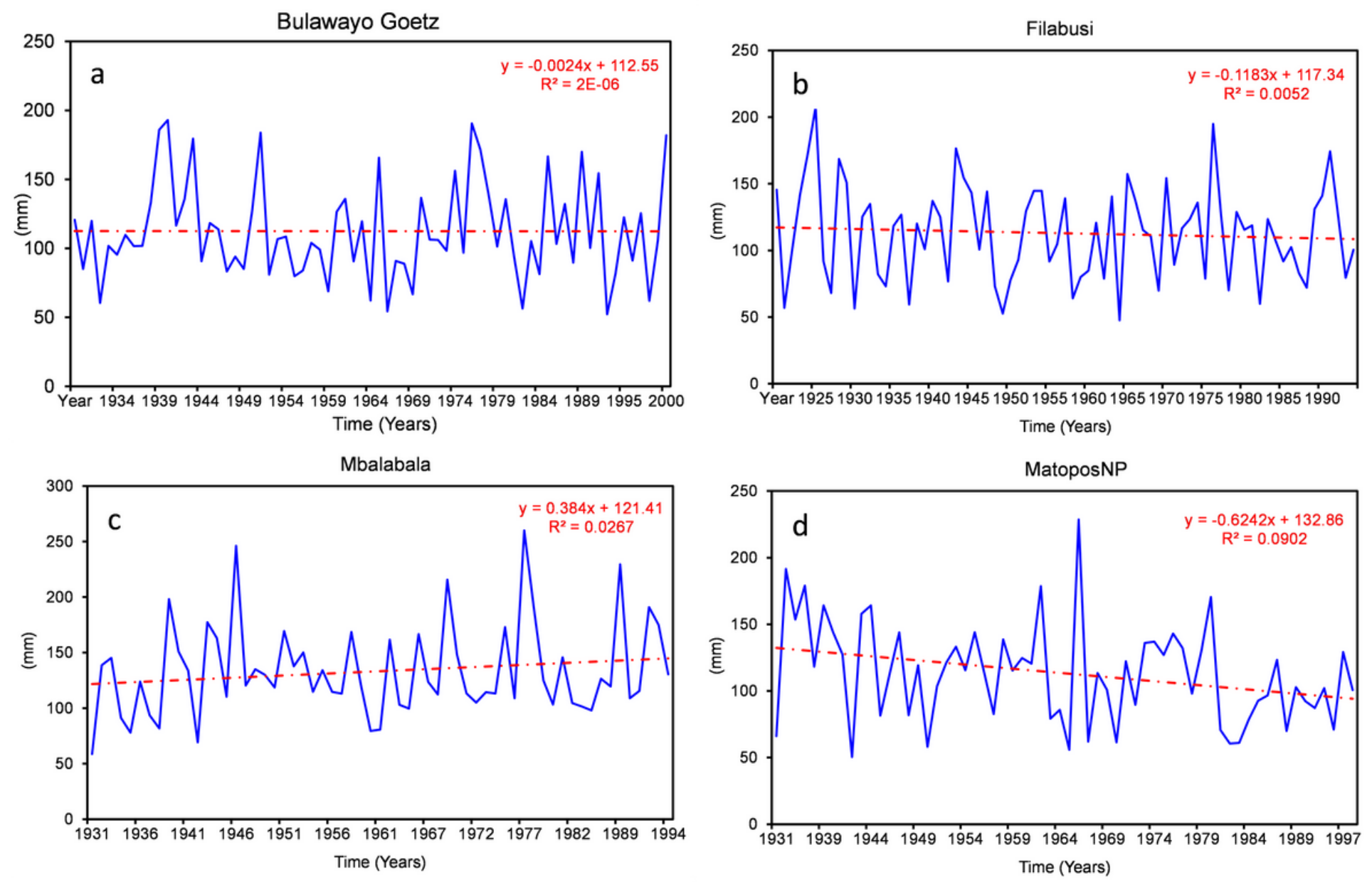

\section{Figure 4}

RX5DAY series trends for the four stations (a - Bulawayo Goetz, b - Filabusi, c - Mbalabala and d Matopos NP). The red dotted lines are linear trend lines illustrating weak and insignificant trends 

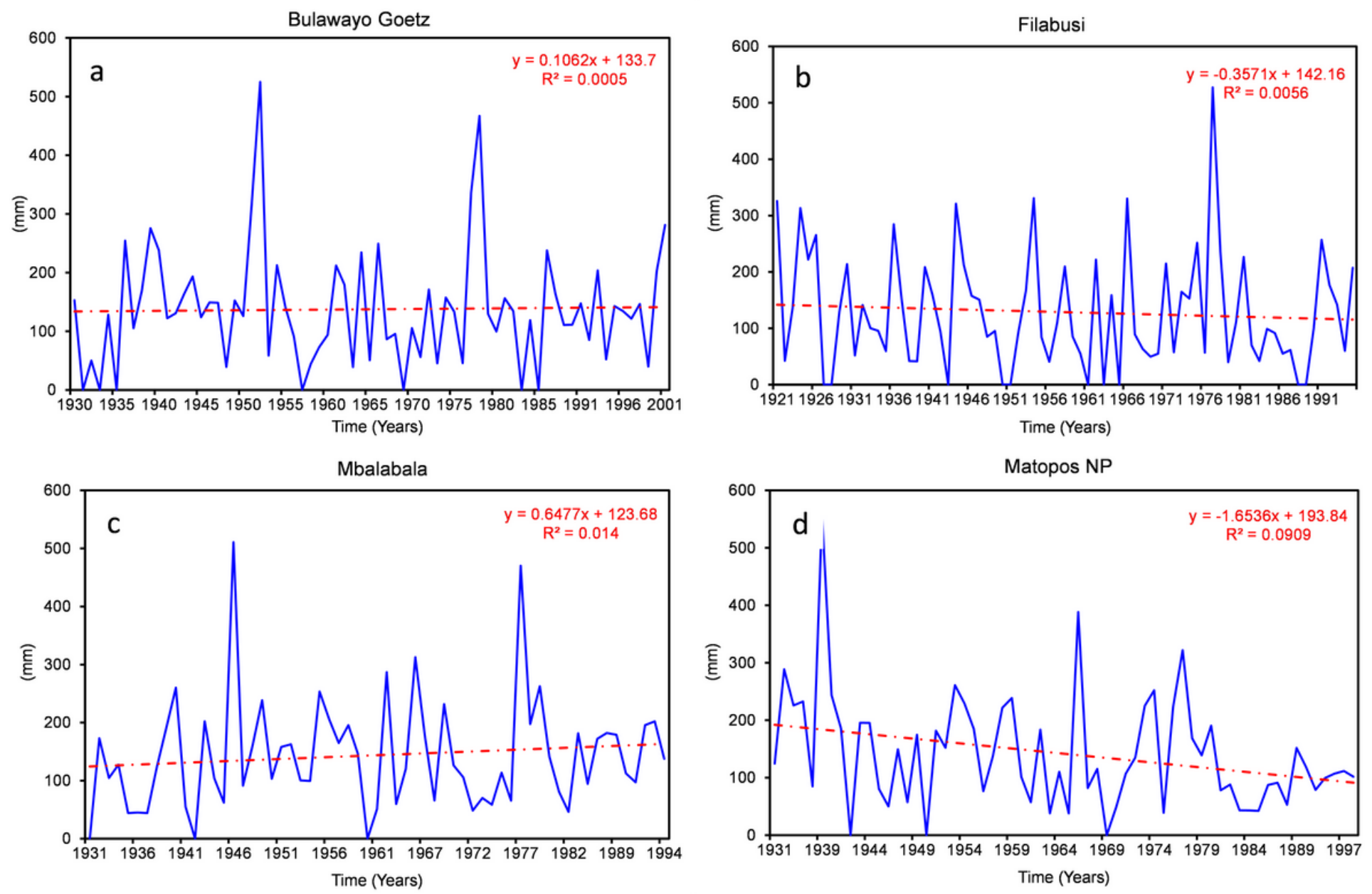

Figure 5

R95p series and trends for the four stations (a - Bulawayo Goetz, b - Filabusi, c - Mbalabala and d Matopos NP). All red dotted lines = insignificant linear trends with MNP only showing a significant declining trend 

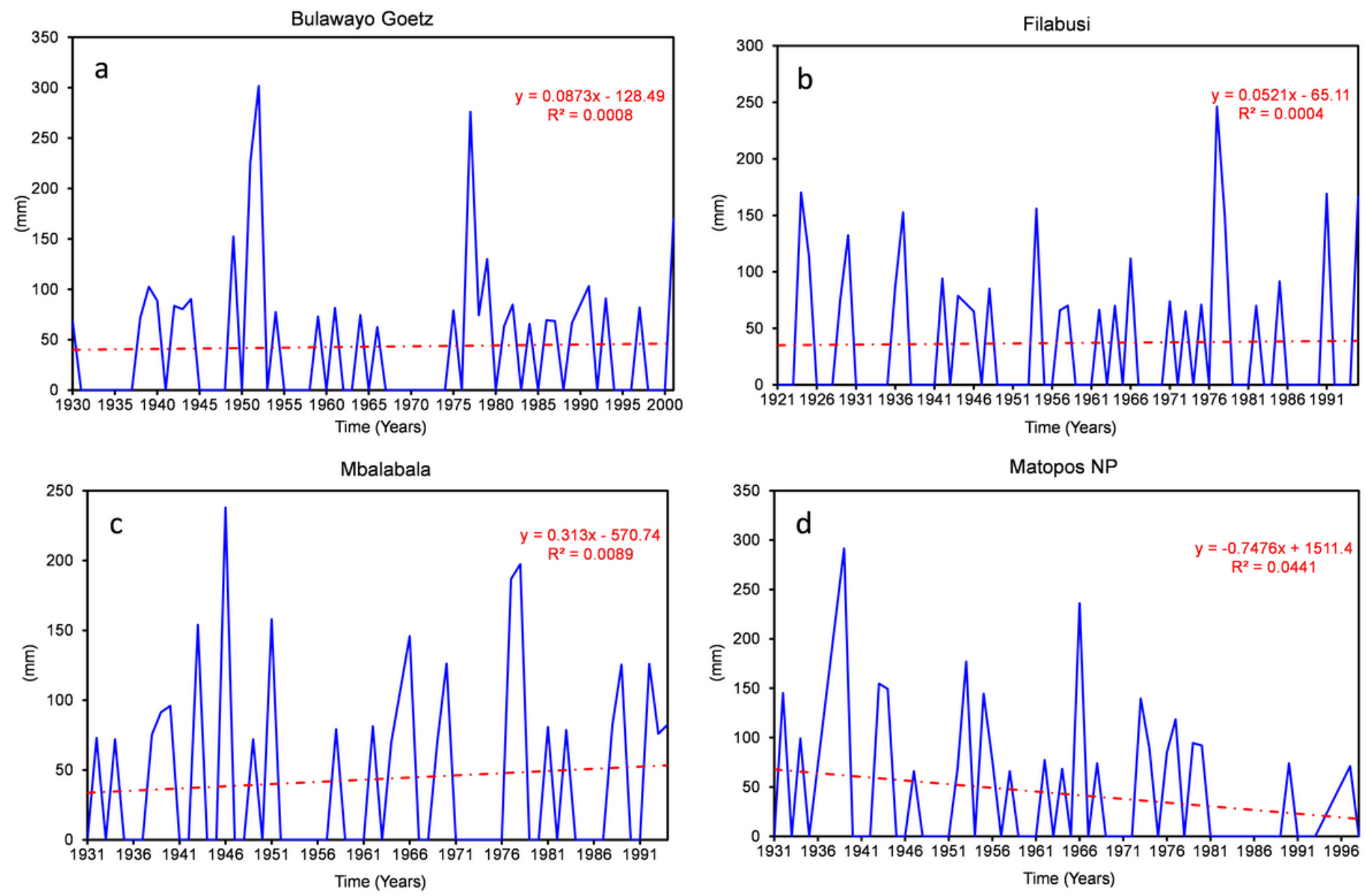

\section{Figure 6}

R99p series and trends for the four stations (a - Bulawayo Goetz, b - Filabusi, c - Mbalabala and d Matopos NP). All red dotted lines = marginally positive, insignificant linear trends for all stations with the exception of MNP having a declining trend over the study period 

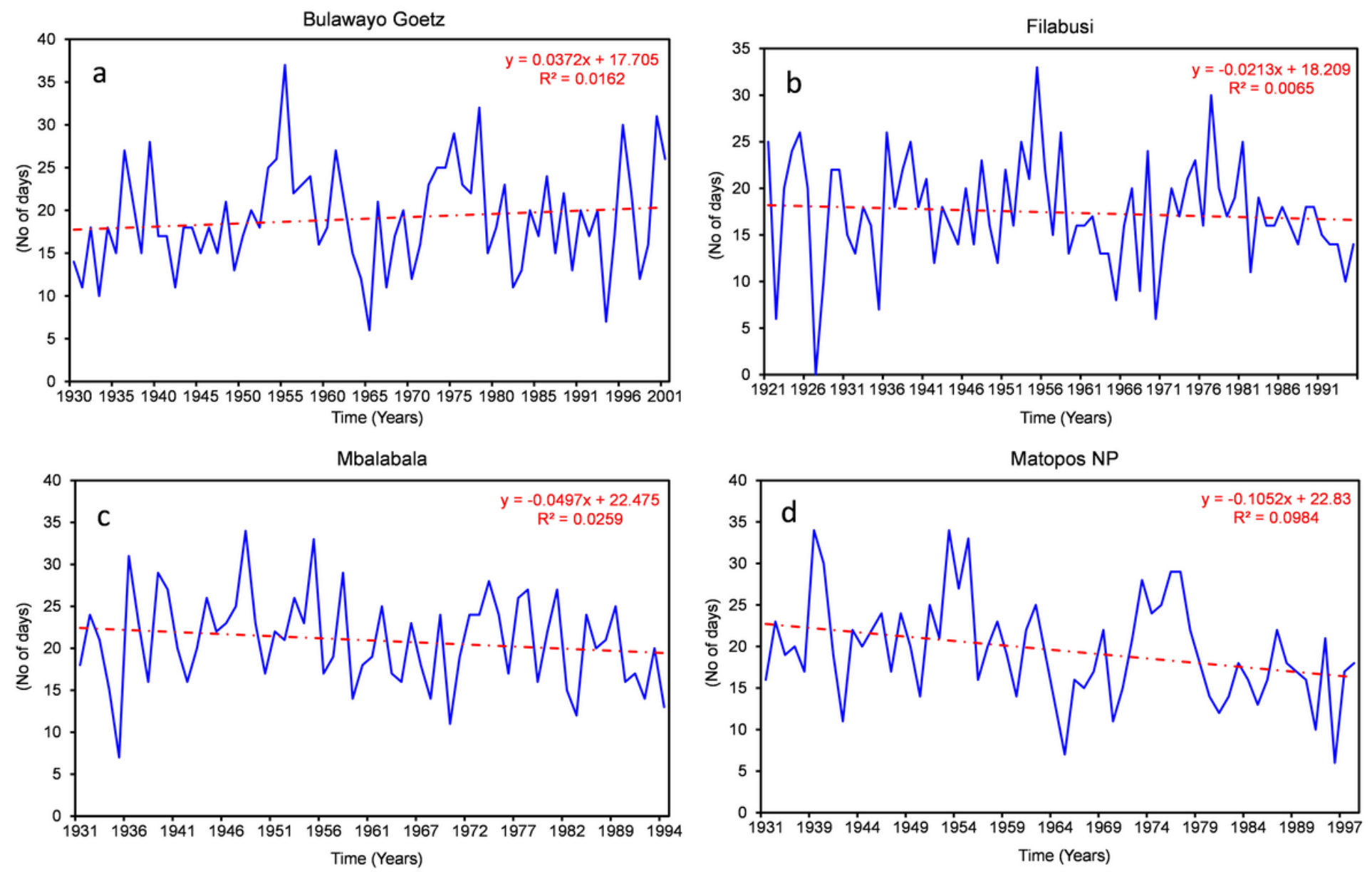

\section{Figure 7}

R10 series and trends for the four stations (a - Bulawayo Goetz, b - Filabusi, c - Mbalabala and d Matopos NP). Red dotted lines = linear trends. All stations show negative trends except Bulawayo Goetz 

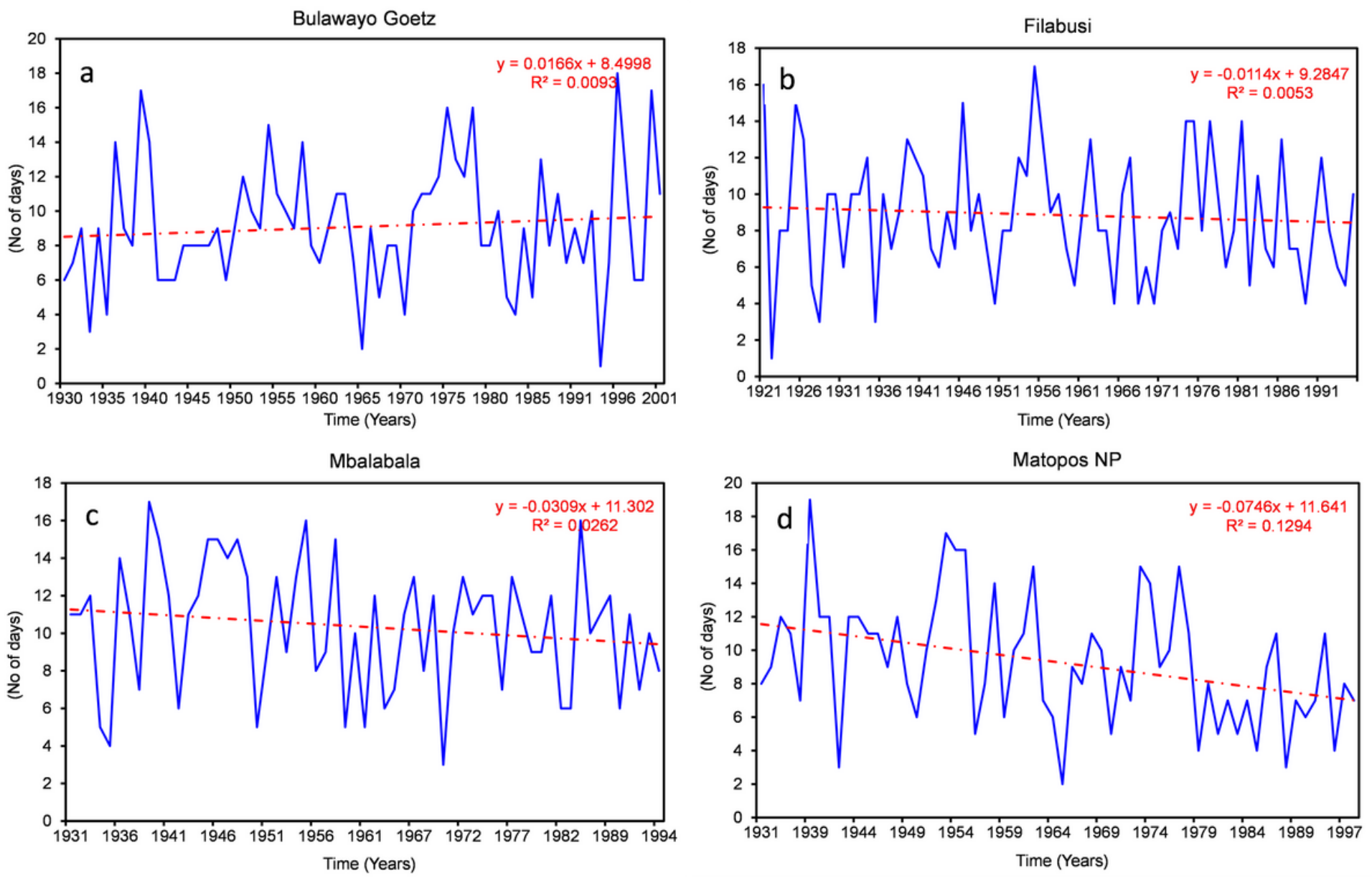

\section{Figure 8}

R20 series and trends for the four stations (a - Bulawayo Goetz, b - Filabusi, c - Mbalabala and d Matopos NP). Red dotted lines $=$ linear trends 

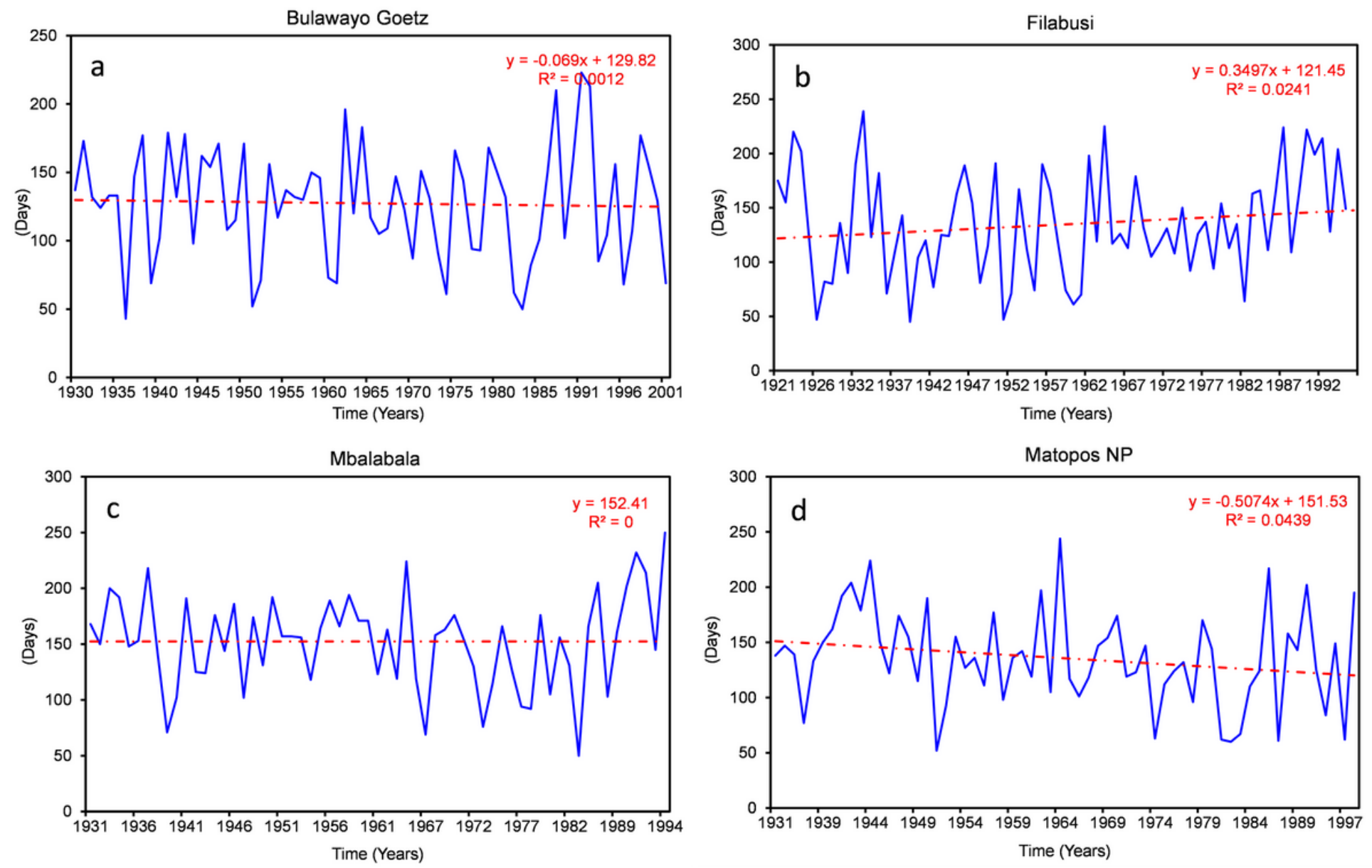

\section{Figure 9}

CDD series and trends for the four stations ( $\mathrm{a}$ - Bulawayo Goetz, b - Filabusi, c - Mbalabala and d Matopos NP). Red dotted lines $=$ linear trends 

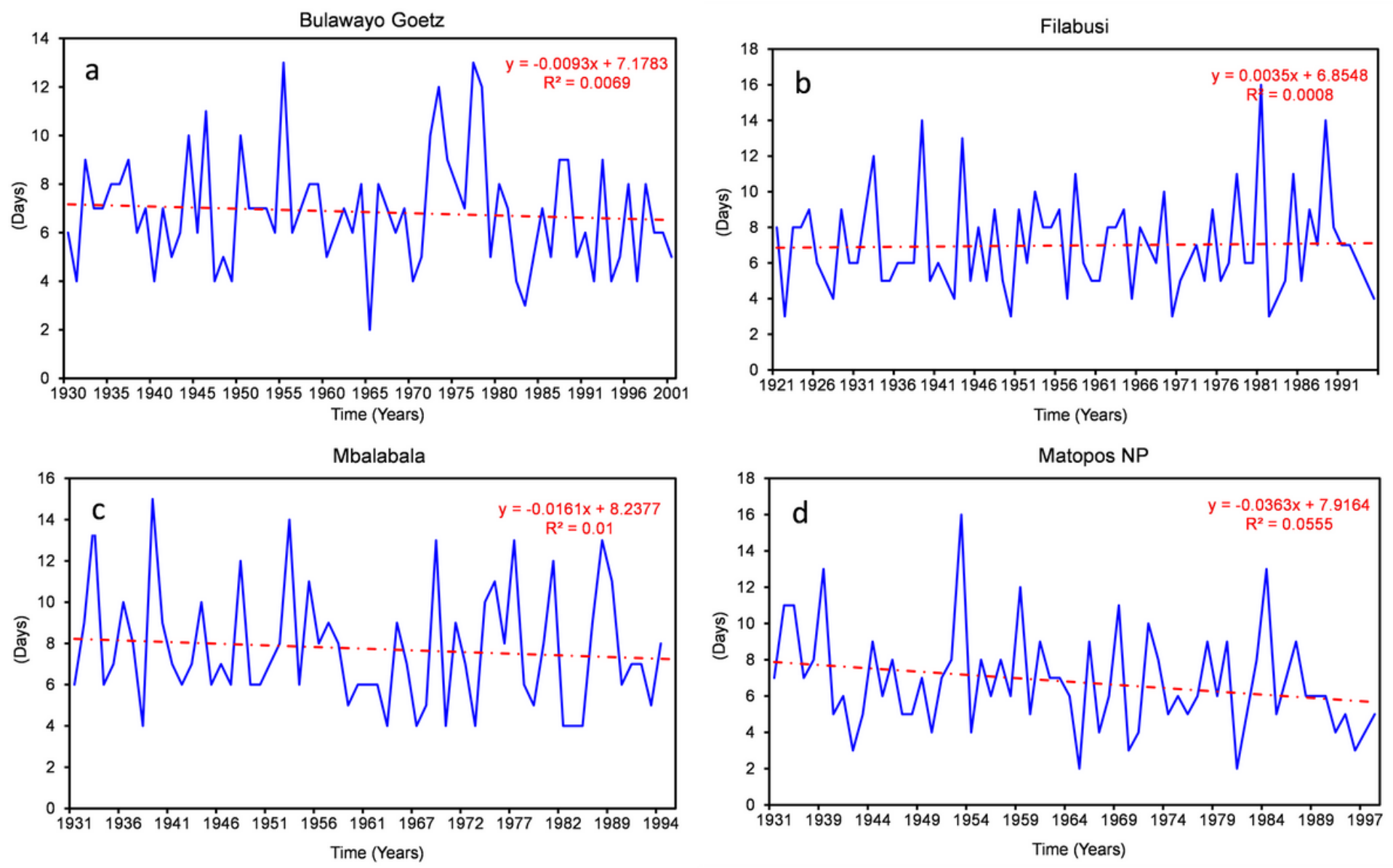

Figure 10

CWD series and trends for the four stations (a - Bulawayo Goetz, b - Filabusi, c - Mbalabala and d Matopos NP). Red dotted lines = negative linear trends with exception for Filabusi station which has a positive trend

\section{Supplementary Files}

This is a list of supplementary files associated with this preprint. Click to download.

- Tables.docx 